\title{
Inhibitory Effects of Nerium oleander L. and Its Compounds, Rutin and Quercetin, on Parthenium hysterophorus L.
}

\author{
M. Rajyalakshmi (Corresponding Author) \\ Department of Biotechnology, B.M.S. College of Engineering, Bangalore 560 019, India \\ Tel: 802-662-2130Ｅ-mail: mrlbmsce@yahoo.co.in
}

\author{
Amruth Kumar N, Divyashree N.R, Kiran Kiran, Pavithra G.S, Rohini. B, Sangeeta. A \& Sindhu Srinivas \\ Department of Biotechnology, B.M.S. College of Engineering \\ Bangalore 560 019, India
}

Received: September 16, $2010 \quad$ Accepted: October 9, $2010 \quad$ doi:10.5539/jas.v3n2p123

\begin{abstract}
Aqueous and methanol extracts of Nerium oleander L. leaves inhibited seed germination (Germination Percentage, Germination Speed, Germination Value and Peak Value) and early growth (root hair formation, root \& shoot lengths of seedlings) of Parthenium hysterophorus L. in a concentration dependent manner. Methanol extracts of white flowered variety showed higher inhibition compared to that of pink flowered variety (at 1:40 dilution of the stock, inhibition was $60 \%$ and $23.4 \%$ with white and pink, respectively) and had $\sim 5$ fold higher levels of Rutin. Rutin and its aglycoside, Quercetin, when mixed with soil affected seed germination, root and shoot lengths of $P$. hysterophorus, though the effects varied at varying concentrations. These results demonstrate that $N$. oleander extracts, Rutin and Quercetin are inhibitory to P.hysterophorus.

SDS-PAGE analysis of P.hysterophorus seedlings grown in presence of $N$. oleander aqueous extracts showed an additional prominent band of $42.66 \mathrm{kDa}$ protein.

Keywords: Nerium oleander, Parthenium hysterophorus, Quercetin, Rutin

\section{Introduction}

$P$. hysterophorus is an obnoxious and aggressively invasive weed of global significance. Its invasiveness and potential for spread is a threat to environment and biodiversity as economically important plants are reduced. In grass lands its invasiveness has reduced the grass by $90 \%$ in some areas (Motooka 2003). P. hysterophorus causes asthma, dermatitis, eczema and hay fever in humans and dermatitis in animals (Lakshmi Chembolli \& Srinivas CR 2007). Physical methods of control of this weed include manual de-weeding before flowering, as de-weeding after flowering leads to increased seed dispersal and germination. Chemical methods of control by herbicides may lead to herbicide resistance by the weed (Adkins et al 1997; Njoroge.J.M.1991) and also serious ecological problems like groundwater contamination further leading to human health hazards. Biological control (Taye Tessema Wondimu 2002) methods like release of insect enemies also have limitations. Management of this weed imparts huge economic burden on the countries where it has aggressively invaded (Review of progress towards implementation of Parthenium weed strategic plan 2006-2007). Moreover, allelopathic effect of P. hysterophorus on other species makes it difficult for the weed management strategies (Singh H P et al 2002; Singh H P et al 2003; Mahadevappa. M 1999 \& Mulatu Wakjira et al 2006). As no single method of control has been successful, an integrated approach is suggested for its effective control (Mahadevappa. M 1999).

$P$. hysterophorus can be suppressed by other plant species which have been studied for their inhibitory effects on this weed (Javaid A 2005; Mahadevappa. M 1999; Sinha Nawalesh K \& Samarjit Singh 2004; Tehmina Anjumi et al 2005). These plant species may produce chemicals that are inhibitory to P. hysterophorus. For e.g. Cassia sericea plant leachates have kaolines, which accumulate in the soil and interfere with this weed (Mahadevappa. M 1999). All the plant species that have been found to be allelopathic to Parthenium, till date, are weeds themselves and are not suitable for weed management. However, allelochemicals that are inhibitory to P. hysterophorus are of importance and hold promise to act as sustainable, environment friendly bio-herbicides.
\end{abstract}


Nerium oleander $\mathrm{L}$ is an ever green ornamental shrub which grows well in warm subtropical regions. It is tolerant to drought and variety of poor soils. It is known to be allelopathic to weed species like Arundo donax (Susan M. Pasternak 2005), Alopecurus myosuroides (black grass), Lactuca sativa (lettuces), Lolium multiflorum (Italian rye-grass) (Nezihi UYGUR. F \& Nevin ISKENDEROGLU. S 1997) and paddy weeds (Tran Dang Khanh et al 2005). N. oleander contains Rutin, Quercetin (flavonoids), oleandrin, neriine (cardiac glycosides), rosagenin (known for its strychnine-like effects), folinerin, neritaloside besides other compounds (Jim Duke 1996 Dr.Duke's Phytochemical and Ethnobotanical database).

Our observation that growth of $P$. hysterophorus is scanty around white flowered $N$. oleander encouraged us to test its possible inhibitory effects on Parthenium. Effect of leaf and root extracts on seed germination, seedling growth and protein expression patterns of $P$. hysterophorus were tested. Lantana camara was used for comparative analysis as it is known to be inhibitory to P. hysterophorus (Mahadevappa M, 1999).

Rutin was found to be in higher concentration in methanol extracts of white flowered variety which showed higher inhibitory levels compared to that of pink variety. Hence we tested the effect of Rutin and its aglycoside, Quercetin, on the germination and early growth of $P$. hysterophorus.

\section{Materials and Methods}

\subsection{Preliminary Studies}

Approximately 3-4 feet tall plants of white flowered Nerium oleander were uprooted from soil, washed thoroughly in running water to remove the soil and were placed in a 1 liter conical flask filled with tap water. This setup was maintained for 48 hours after which the water was collected and filtered using Whatman no. 1 filter paper. This root leachate was used for the Germination assay in Petri plates containing soil in which 20 presoaked sterilized Parthenium seeds were sown. Two $\mathrm{ml}$ of root leachate was added to each petriplate on a daily basis for 9 days.

\subsection{Preparation of Aqueous and Methanol Extracts of N. oleander / L. camara}

Freshly collected $N$. oleander / L. camara leaves were extensively washed, wiped, oven-dried (at $50^{\circ} \mathrm{C}$ for $48 \mathrm{hrs}$ ) and were finely powdered. The powder was stirred in water/ methanol $(100 \mathrm{~g}$ in $500 \mathrm{ml})$ for $24 \mathrm{hrs}$, filtered using muslin cloth, and was centrifuged at $5,000 \mathrm{~g}$ for $10 \mathrm{~min}$. The supernatant was filter-sterilized $(0.22 \mu \mathrm{m}$, Millipore $)$ and stored at $4^{\circ} \mathrm{C}$. In case of methanol extracts, methanol in the supernatant was completely evaporated, the residue suspended in water (volume equal to that of aqueous extract) and filter sterilized.

The dry weight of aqueous and methanol stock extracts of white Nerium leaves was calculated by evaporating the solvent completely. See section 3.22

\subsection{Bioassays on germination paper}

P. hysterophorus seeds were sterilized by treating with 4\% Sodium hypochlorite for 5 min. Twenty presoaked sterilized seeds were placed in each Petri plate with germination paper. $2 \mathrm{ml}$ of extracts of different concentrations was added daily for 9 days. Triplicates were maintained for each concentration. The percentage of seeds germinated, root hairs and lengths of root \& shoot were studied. Germination Speed, Germination Value and Peak Value were calculated (Czabator F.J. 1962). Results were analyzed using Student's t-test. The dilutions that gave $50 \%$ inhibition were noted.

\subsection{Protein Expression Analysis by SDS-PAGE}

Parthenium seedlings which were treated with leaf extracts (1:5 dilution of aqueous and 1:10 dilution of methanol - concentrations that allowed germination to some extent but reduced root and shoot length) of white $N$. oleander / L. camara from day 1 to day 9 were taken for protein preparation which was analyzed in SDS-PAGE.

\subsubsection{Procedure for Total Protein Preparation}

Parthenium seedlings were homogenized in extraction buffer $(0.25 \mathrm{M}$ Tris $\mathrm{HCl}, 0.5 \mathrm{M}$ EDTA, $0.5 \mathrm{M} \mathrm{NaCl}, 0.1 \%$ SDS, $100 \mu \mathrm{g} / \mathrm{ml}$ PMSF, pH 6.8) (5ml of buffer/gm weight). The homogenate was centrifuged at $10,000 \mathrm{~g}$ for 10 min at $4^{\circ} \mathrm{C}$ and the supernatant was precipitated with $10 \%$ TCA. The precipitate was washed with acetone and reconstituted in the same buffer.

\subsubsection{SDS-PAGE}

Electrophoresis was conducted as per the modified procedure of Laemmli (Vichai Boonsaeng 1984). For separating gel, a discontinuous gradient of $8 \%, 10 \%$ and $12 \%$ polyacrylamide was used. The stacking gel was of $4.5 \%$ polyacrylamide. Equal amount of protein (i.e., $20 \mu \mathrm{g} /$ well) was loaded to each well and was electrophoresed at 50mA. Gels were silver stained using the procedure of J.H. Morrissey (James H. Morrissey 1981). 


\subsection{TLC Analysis}

Methanol extracts of leaves of both pink and white varieties of $N$. oleander were analyzed in TLC using pure Rutin (Sigma Aldrich) as standard. Precoated $20 \mathrm{~cm}$ x $20 \mathrm{~cm}$ TLC plates (silica gel $60 \mathrm{~F}_{254}$, Merck, Germany) were used for separation of samples. Solvent system used was Ethyl acetate: Formic acid: Water in 85:10:15, and the bands were detected under UV ( $254 \mathrm{~nm})$. Solvent front was noted and Rf values were calculated.

\subsection{HPLC Analysis}

Leaf extracts of pink / white varieties of $N$. oleander were analyzed in reverse phase HPLC [Shimadzu Company, SPD-20A]. All samples were filtered through $0.22 \mu \mathrm{m}$ filters [Millipore (India) Pvt. Ltd] prior to use and $20 \mu \mathrm{l}$ was loaded for each run. Standard graph of Rutin (HPLC grade, Sigma Aldrich) was used to calculate the concentrations of Rutin in the extracts.

For all methanol extracts, Acetonitrile: $0.1 \%$ trichloroacetic acid $(75: 25)$ was used as mobile phase at $245 \mathrm{~nm}, 27^{0}$ $\mathrm{C}$ oven temperature of the column, and at $1.5 \mathrm{ml} / \mathrm{min}$ flow rate.

For aqueous extracts, $5 \%$ Acetic acid in Acetonitrile: Water (80:20) was used as mobile phase at $373 \mathrm{~nm}, 40^{\circ} \mathrm{C}$ oven temperature of the column, and at $1 \mathrm{ml} / \mathrm{min}$ flow rate. Here both Rutin and Quercetin were used as standards.

\subsection{Effect of Rutin and Quercetin on germination and early growth of P. hysterophorus}

Rutin and/or Quercetin (Xi' an Metals and Minerals, China) were directly added to soil in Petri plates (on day-1 and day-4) in which presoaked sterilized seeds were sown. A range of concentrations were tested maintaining triplicates and 20 seeds per plate. Percentage of seeds germinated, root and shoot lengths were observed for 9 days (Table 2). Germination Speed, Germination Value and Peak Value were calculated, and results analyzed using Student's t-test and 1-way ANOVA (Ronald E Walpole et al 2006).

\section{Results}

\subsection{Preliminary Studies}

In the preliminary assays conducted with white Nerium root leachates, complete inhibition of Parthenium seed germination was observed.

\subsection{Bioassays on germination paper}

To test the effects of $N$. oleander extracts on P. hysterophorus in the absence of complex interactions that may take place in the soil due to biotic and abiotic factors, germination studies were carried out on germination paper in Petri plates.

\subsection{1}

Bioassays were done with white Nerium leaf aqueous extracts using Lantana for comparison. Significant reduction in the $\%$ of Parthenium seeds germinated was observed in presence of the extracts (Fig. 1). With the increase in the concentration, the germination speed (G.S), peak value (P.V) and germination value (G.V) decreased (Fig 2 and Fig 3). Root hair development, and root \& shoot lengths were also reduced significantly (Table 1 and Fig. 4). Compared to Lantana, inhibition by Nerium extracts was more (Fig. 1 \& Fig. 4) at comparable dilution of the extracts.

\section{2 .2}

To test whether the inhibition observed above (as in section 3.2.1) was due to the toxicity, germination bioassays were repeated with higher dilutions and with both aqueous and methanol extracts of leaves/roots of two varieties of Nerium, white and pink flowered. Higher level of inhibition was observed with methanol extracts of white Nerium leaves, compared to that of pink (At 1:40 dilution, the inhibition was $60 \%$ and $23.4 \%$ for white and pink, respectively) (Fig 5 and Table 2).

In case of leaf aqueous extracts, no difference in the level of inhibition was observed between pink and white varieties (Fig $5 \&$ Table 2). Root extracts of pink and white Nerium did not show variation either (Results not shown).

The trend in germination value (G.V), peak value (P.V) and germination speed (G.S) is as shown in Fig 6 \& Fig 7 .

The dry weights of aqueous and methanol stock extracts of white Nerium leaves corresponded to $35.4 \mathrm{mg} / \mathrm{ml}$ and $58.1 \mathrm{mg} / \mathrm{ml}$, respectively.

\subsection{SDS-PAGE}

In SDS-PAGE analysis of protein preparations of the seedlings germinated and grown in presence of $N$. oleander/ L. camara aqueous extracts (1:5 dilutions of stock- a concentration that allowed germination to some extent but 
reduced root and shoot length - Fig 8), a protein band corresponding to $42.66 \mathrm{kDa}$ appeared. Appearance of this prominent band was consistent in repeated experiments. However, the seedlings treated with Nerium/Lantana methanol extracts did not show this band (Fig. 8).

\subsection{TLC Analysis}

Rutin band was observed in both pink and white $N$. oleander leaf methanol extracts. Concentration of Rutin in the white flowered variety was much more as observed by the intensity of the band (Fig 9).

\subsection{HPLC Analysis}

To determine the exact concentration of Rutin in Nerium methanol extracts, HPLC was performed. Methanol extracts of Nerium white and pink contained $7.04 \times 10^{-4} \mathrm{M}$ and $1.31 \times 10^{-4} \mathrm{M}$ of Rutin respectively (Fig 10 \& Fig 11).

In aqueous extracts, peaks corresponding to Rutin and Quercetin were detected. Although Rutin peak was distinct, other compounds were not resolved completely (Fig 12).

\subsection{Effect of Rutin and Quercetin on P. hysterophorus}

\subsubsection{Effect of Rutin}

Percentage of seeds germinated decreased with the increasing concentrations of Rutin (Fig. 13). The germination speed (G.S), germination value (G.V) and peak value (P.V) decreased with the increasing concentrations (See Table 3 \& Fig. 14 and 15). Root lengths reduced at and above $3 \mathrm{mg} / \mathrm{gm}$ of soil, while below this concentration all the seedlings had increased root lengths, some of them exceptionally longer(2-3 times longer than the average of controls). Shoot lengths reduced at and above $6 \mathrm{mg} / \mathrm{gm}$ of soil, while below this concentration, all the seedlings had increased shoot lengths. See Table 2 \& Fig. 16) For Student's t-test and 1-way ANOVA results see Table 3 and 4.

\subsubsection{Effect of Quercetin}

Although the $\%$ seed germination reduced $(<50 \%$ of control for all concentrations tested), there was no concentration dependent variation. The Germination Speed is less compared to that of Rutin (See Table 3, Fig. 13, Fig 14 and Fig 15). At 6mg/gm a decrease in root and shoot length was observed. Treatment with Quercetin caused increased root and shoot lengths in the seedlings germinated at $<6 \mathrm{mg} / \mathrm{gm}$. Few roots were exceptionally longer i.e. 2-4 times than the average of controls (See Table 3 \& Fig. 17). For Student's t-test and 1-way ANOVA results see Table 3 and 4.

\subsubsection{Effect of Rutin(R) \& Quercetin (Q) in Combination}

The \% seed germination reduced in presence of these compounds (Fig. 13, Fig 14 and Fig 15). Root lengths decreased for concentrations at and above $3 \mathrm{R}+3 \mathrm{Q} \mathrm{mg} / \mathrm{gm}$ of soil, whereas below this concentration, all the seedlings had increased root lengths, some of them 3-4 times longer than the average of the control. This trend is similar to that of Rutin treatment (See Table 3 \& Fig. 18). For Student's t-test and 1-way ANOVA results see Table 3 and 4.

\section{Discussion}

The present study was initiated with the aim of exploring the inhibitory effects of $N$. oleander. Both aqueous and methanol extracts of white Nerium leaves inhibited Parthenium seed germination and early growth. When tested on seed germination and early growth of crop plants, Nerium extracts had no effect on wheat, Ragi, Green gram and Soya gram seeds even at 1:3 dilution of the stock preparation (Results not shown here).

Of the two varieties of Nerium tested, methanol extracts showed quantitative difference in the inhibition level of seed germination (at 1:40 dilution of the stock, inhibition was $60 \%$ and $20 \%$ with white and pink, respectively). Quantitative difference in the concentration of Rutin (5 fold more in white variety) in these extracts might account for this difference. Hence we tested the effect of pure Rutin and its aglycoside, Quercetin, on Parthenium seed germination. Approximately, $90 \%$ inhibition of seed germination was observed at $1.5 \mathrm{mg}$ of Rutin per gm of soil. As Rutin is sparingly soluble in water, i.e. $\sim 125 \mathrm{mg} / \mathrm{L}$ (HMDB in 'Reference') the actual amount of Rutin that is picked up by the seedlings might be much less.

Both Rutin and Quercetin increased the root and shoot lengths at lower concentrations (in the seedlings that could germinate at these concentrations), whereas, inhibited the same at higher concentrations. This correlates with the previous studies that phenolic allelochemicals at lower concentrations may be stimulatory where as inhibitory at higher concentrations in the receiving species (Francisco A Macias 2004; Rizvi S.J.H \& Rizvi V 1992).

As analyzed in SDS-PAGE, a new protein band was observed in $P$. hysterophorus seedlings grown in presence of $N$. oleander aqueous extracts. More detailed expression analysis in 2D PAGE and/or microarray is required to 
identify the genes that are responsible for morphological changes in P. hysterophorus on exposure to Nerium extracts / pure compounds. A time bound expression analysis of the proteome under the influence of these extracts/compounds may help us to delineate the complex inhibitory mechanisms. Also, the effect of Nerium extracts and its pure compounds on crop plants have to be studied in more detail for practical applications.

\section{Conclusion}

These preliminary studies showed that $N$. oleander extracts and Rutin \& Quercetin did affect the early growth and germination of $P$. hysterophorus. Other compounds of $N$. oleander have to be tested for their inhibitory effects. The interactions of these compounds with biotic and abiotic soil factors have to be investigated that may help us to gain insights into the inhibitory mechanisms and in turn may lead to future potential bio-herbicide against $P$. hysterophorus.

\section{Acknowledgements}

We thank Xi'an metals and minerals, China, for providing Rutin and Quercetin free of cost. Our heartfelt thanks to Dr. M. Mahadevappa - retired Vice-chancellor University of Agricultural Sciences, Dharwad, and Dr. Devendra.R - Head, Crop Physiology Department, University of Agricultural Sciences, GKVK, Bangalore for their valuable suggestions. We sincerely thank Prof. Balakrishna Gowda, Head of Forestry and Environmental Sciences, Dr.Umashankar \& Dr.Priti.P.V. of Crop Physiology Department, University of Agricultural Sciences, GKVK Bangalore, for allowing us to use reverse phase HPLC system. We are grateful to Dr.R.L.Ravikumar, Agricultural University, Hassan, for his support and help. We also thank Dr. Alpana Pande for her valuable discussions regarding HPLC.

\section{References}

Adkins, S.W., Wills, D., Boesrsm, M., Walker, S.R., Robinson, G., Mcleod, R.J., \& Einam, J.P. (1997). Weeds resistant to chlorsulfuron and atrazine from the north-east grain region of Australia. Weed Research, 37, 343-349.

Czabator, F.J. (1962). Germination value: An index combining speed and completeness of pine seed germination. Forest Science, 8, 386-396.

Jim Duke. (1996). Dr. Duke's Phytochemical and Ethnobotanical database. [Online] Available: http://www.ars-grin.gov/duke/_

Francisco A Macias, Jauancg Galindo, \& Josema Molinillo. (2004). Allelopathy: Chemistry and Mode of Action of Allelochemicals. CRC Press.

HMDB - Human Metabolome Database. [Online] Available: http://hmdb.ca/scripts/show_card.cgi?METABO $\mathrm{CARD}=\mathrm{HMDB} 03249$

James H. Morrissey. (1981). Silver Stain for Proteins in Polyacrylamide gels: A Modified Procedure with Enhanced Uniform Sensitivity. Analytical Biochemistry, 117(2), 307-310.

Javaid, A., Bajwa, R., \& Anjum, T. (2005). Biological Control of P. hysterophorus II: Allelopathic effect of Desmostachya bipinnata on distribution and early seedling growth of Parthenium hysterophorus L. International Journal of Biology and Biotechnology, 2(2), 459-463.

Lakshmi Chembolli, \& Srinivas, C.R. (2007). Parthenium: A wide angle view. Indian Journal of Dermatology, Venereology and Leprology, 73, 296-306.

Mahadevappa, M. (1999). P. hysterophorus and its Management. Dharwad, India: University of Agricultural Sciences.

Motooka, Philip, Luisa Castro, Duane Nelson, Guy Nagai, \& Lincoln Ching. (2003). Weeds of Hawaii's Pastures and Natural Areas: An Identification and Management Guide. Hawaii: College of Tropical Agriculture and Human Resources, University of Hawaii at Manoa.

Mulatu Wakjira, Gezahegn Berecha, \& Befekadu Bulti. (2006). Allelopathic effects of Parthenium hysterophorus extracts on seed germination and seedling growth of lettuce. Tropical Science, 45(4), 159-162.

Nezihi UYGUR, F., \& Nevin ISKENDEROGLU, S. (1997). Allelopathic and Bioherbicide Effects of Plant Extracts on Germination of Some Weed Species. Turkish Journal of Agriculture and Forestry, 21, 177-180.

Njoroge, J.M. (1991). Tolerance of Bidens pilosa L and P. hysterophorus L to paraquat (Gramoxone) in Kenya coffee. Kenya Coffee, 56: 999-1001. 
Review of progress towards implementation of Parthenium weed strategic plan. (2006-2007). Australia: National Parthenium Weed Management Group [Online] Available: http://www.weeds.org.au/WoNS/parthenium/docs/ Parthenium_Strategic_Plan_Review_2006-07.pdf

Rizvi, S.J.H, \& Rizvi,V. (1992). Allelopathy: Basic and Applied Aspects. London: Chapman \& Hall.

Ronald E Walpole, Raymond Myers, \& Sharon L. Myers. (2006). Probability and Statistics for Engineers and Scientists. Pearson Prentice Hall.

Singh, H.P., Batish, D.R., Kohli, R.K., Saxena, D.B., \& Arora, V. (2002). Effect of Parthenin-A sesquiterpene Lactone from Parthenium hysterophorus- on early growth and physiology of Ageratum conyzoides. Journal of Chemical Ecology, 28(11), 2169-79.

Singh, H.P., Batish, D.R., Pandher, K., \& Kohli, R.K. (2003). Assessment of allelopathic properties of Parthenium hysterophorus residues. Agriculture, Ecosystems \& Environment, 95: 537-541.

Sinha Nawalesh, K., \& Samarjit Singh. (2004). Allelopathic effects of Xanthium strumarium on Parthenium hysterophorus. Indian Journal of Plant Physiology, 9, 313-315.

Susan M. Pasternak. (2005). Nature vs. Nature: Eradicating Arundo donax with allelopathic leaf extract treatments. California State Science Fair. [Online] Available: http://www.usc.edu/CSSF/History/2005/Projects /J1428.pdf

Taye Tessema Wondimu. (2002). Investigation of Pathogens for Biological Control of P. hysterophorus (Parthenium hysterophorus L.) in Ethiopia. Germany: DAAD FellowshipBerlin.

Tehmina Anjum, Rukhsana Bajwa, \& Arshad Javaid. (2005). Biological Control of Parthenium I: Effect of Imperata cylindrica on Distribution, Germination and Seedling Growth of Parthenium hysterophorus L. International Journal of Agriculture \& Biology, 07(3), 448-450.

Tran Dang Khanh, Nguyen Huu Hong, Tran Dang Xuan, \& III Min Chung. (2005). Paddy weed control by medicinal and leguminous plants from Southeast Asia. Crop Protection, 24(5), 421-431.

Vichai Boonsaeng. (1984). Analysis of Proteins by SDS PAGE. In: Natth Bhamarapravati, Sakol Panyim, \& Yongyuth Yuthavong, Genetic Engineering Techniques in Tropical Disease Research (pp. 229-236). Thailand: Mahidol University.

Weed Management Guide; Natural Heritage trust, Australia. [Online] Available: http://www.weeds.org.au/docs/ parthenium_weed_mgt_guide.pdf ISBN 1-920932-12-7.

Table 1. Effect of Aqueous extracts of $N$. oleander/ L. camara leaves, on the root and shoot lengths of $P$. hysterophorus seedlings ${ }^{\#}$

\begin{tabular}{|c|c|c|c|c|c|c|}
\hline Extract added & $\begin{array}{c}\text { Dilution of } \\
\text { Stock } \\
\text { Extract }\end{array}$ & $\begin{array}{c}\% \\
\text { Inhibition** }\end{array}$ & $\begin{array}{l}\text { Average Root Length } \\
\text { (of seedlings } \\
\text { germinated) } \\
\mathrm{cm}\end{array}$ & $\begin{array}{l}\text { t-value } \\
\text { (for root } \\
\text { length) }\end{array}$ & $\begin{array}{l}\text { Average Shoot } \\
\text { Length(of } \\
\text { seedlings } \\
\text { germinated) } \\
\mathrm{cm} \\
\end{array}$ & $\begin{array}{l}\text { t-value } \\
\text { (for } \\
\text { shoot } \\
\text { length) }\end{array}$ \\
\hline $\begin{array}{c}\text { No extract } \\
\text { added } \\
\text { (Control) }\end{array}$ & & 0 & 1.39 & & 1.15 & \\
\hline \multirow{4}{*}{$\begin{array}{l}N . \text { oleander } \\
\text { aqueous }\end{array}$} & $1: 0$ & 100 & 0 & -* & 0 & -* \\
\hline & $1: 1$ & 85.29 & 0.25 & 6.68 & 0.3 & 6.60 \\
\hline & $1: 5$ & 80.05 & 0.38 & 8.08 & 0.86 & 3.84 \\
\hline & $1: 10$ & 60.74 & 0.46 & 12.7 & 0.86 & 4.32 \\
\hline \multirow{4}{*}{$\begin{array}{l}\text { L. camara } \\
\text { Aqueous }\end{array}$} & $1: 0$ & 100 & 0 & -* & 0 & -* \\
\hline & $1: 1$ & 100 & 0 & -* & 0 & -* \\
\hline & $1: 5$ & 67.212 & 0.6 & 7.22 & 1.26 & -1.30 \\
\hline & $1: 10$ & 37.31 & 0.76 & 10.2 & 1.33 & -2.34 \\
\hline
\end{tabular}

${ }^{\#} \mathrm{t}$-values obtained by unpaired Student's t-tests at $\mathbf{P}=\mathbf{0 . 0 5}$ and $\mathbf{t}$-critical $\approx \mathbf{2 . 0 5}$

$* t$-value could not be obtained as the no. of seeds germinated was less

** Control taken as zero 
Table 2. Effect of Aqueous/Methanol extracts of $N$. oleander (pink and white flowered varieties) leaves, on the root \& shoots lengths of $P$. hysterophorus seedlings ${ }^{\#}$

\begin{tabular}{|c|c|c|c|c|c|c|}
\hline Extract Added & $\begin{array}{l}\text { Dilution of } \\
\text { Stock Extract }\end{array}$ & $\begin{array}{c}\% \text { of } \\
\text { Inhibition }\end{array}$ & $\begin{array}{c}\text { Average Root } \\
\text { Length of seedlings } \\
\text { germinated(in } \mathrm{cm})\end{array}$ & $\begin{array}{l}\text { t-value } \\
\text { (for root } \\
\text { length) }\end{array}$ & $\begin{array}{c}\text { Average shoot } \\
\text { length of seedlings } \\
\text { germinated (in cm) }\end{array}$ & $\begin{array}{l}\text { t-value (for } \\
\text { shoot } \\
\text { length) } \\
\end{array}$ \\
\hline Control & & 0 & 1.5 & - & 1.1 & - \\
\hline $\begin{array}{l}\text { Nerium leaf } \\
\text { aqueous(pink) }\end{array}$ & $\begin{array}{c}1: 5 \\
1: 10 \\
1: 20 \\
1: 40 \\
\end{array}$ & $\begin{array}{c}90.1 \\
63.63 \\
50.9 \\
49.1 \\
\end{array}$ & $\begin{array}{l}0.12 \\
0.33 \\
0.37 \\
0.63 \\
\end{array}$ & $\begin{array}{c}5.13 \\
8.4 \\
9.85 \\
5.26 \\
\end{array}$ & $\begin{array}{c}0.32 \\
0.6 \\
0.62 \\
0.65 \\
\end{array}$ & $\begin{array}{l}4.72 \\
8.38 \\
9.39 \\
7.89 \\
\end{array}$ \\
\hline $\begin{array}{l}\text { Nerium leaf } \\
\text { methanol (pink) }\end{array}$ & $\begin{array}{c}1: 5 \\
1: 10 \\
1: 20 \\
1: 40\end{array}$ & $\begin{array}{c}98.18 \\
74.54 \\
69.1 \\
23.4\end{array}$ & $\begin{array}{c}0 \\
0.43 \\
0.5 \\
0.37\end{array}$ & $\begin{array}{c}-* \\
5.88 \\
6.04 \\
5.68\end{array}$ & $\begin{array}{c}0.1 \\
0.53 \\
0.65 \\
0.53\end{array}$ & $\begin{array}{c}-* \\
7.31 \\
6.72 \\
5.57\end{array}$ \\
\hline $\begin{array}{l}\text { Nerium leaf } \\
\text { aqueous (white) }\end{array}$ & $\begin{array}{c}1: 5 \\
1: 10 \\
1: 20 \\
1: 40 \\
\end{array}$ & $\begin{array}{c}74.54 \\
60 \\
27.27 \\
52.72 \\
\end{array}$ & $\begin{array}{c}0.42 \\
0.483 \\
0.63 \\
0.8 \\
\end{array}$ & $\begin{array}{c}4.99 \\
6.82 \\
5.49 \\
3.6 \\
\end{array}$ & $\begin{array}{l}0.72 \\
0.76 \\
0.73 \\
0.53 \\
\end{array}$ & $\begin{array}{l}5.93 \\
6.21 \\
8.73 \\
6.54 \\
\end{array}$ \\
\hline $\begin{array}{l}\text { Nerium leaf } \\
\text { methanol (white) }\end{array}$ & $\begin{array}{c}1: 5 \\
1: 10 \\
1: 20 \\
1: 40\end{array}$ & $\begin{array}{c}90.1 \\
89.1 \\
90.1 \\
60\end{array}$ & $\begin{array}{l}0.63 \\
0.22 \\
0.50 \\
0.55\end{array}$ & $\begin{array}{l}4.91 \\
5.03 \\
3.55 \\
3.64\end{array}$ & $\begin{array}{c}0.45 \\
0.38 \\
0.4 \\
0.65\end{array}$ & $\begin{array}{l}5.67 \\
6.18 \\
4.99 \\
4.86 \\
\end{array}$ \\
\hline
\end{tabular}

\# The t-values obtained by unpaired Student's t-tests at $\mathbf{P}=\mathbf{0 . 0 5}$ and $\mathbf{t}$-critical $\approx \mathbf{2 . 0 1}$

* t-value could not be obtained as the no. of seeds germinated was less

** Control taken as zero

Table 3. Effect of Rutin / Quercetin / Rutin + Quercetin on the Root and Shoot lengths of P. hysterophorus seedlings ${ }^{\#}$

\begin{tabular}{|c|c|c|c|c|c|c|}
\hline $\begin{array}{c}\text { Chemical } \\
\text { added }\end{array}$ & \multicolumn{2}{|c|}{$\begin{array}{c}\text { Concentration of } \\
\text { chemical added } \\
\text { (mg/gm of soil) }\end{array}$} & $\begin{array}{c}\text { Average Root } \\
\text { Length of seedlings } \\
\text { germinated (in cm) }\end{array}$ & $\begin{array}{c}\text { t-value } \\
\text { (for root } \\
\text { length) } \\
\end{array}$ & $\begin{array}{c}\text { Average Shoot } \\
\text { Length of seedlings } \\
\text { germinated (in cm) }\end{array}$ & $\begin{array}{c}\text { t-value } \\
\text { (for shoot } \\
\text { length) }\end{array}$ \\
\hline $\begin{array}{c}\text { No chemical } \\
\text { added } \\
\text { (Control) }\end{array}$ & & & 2.87 & & 1.95 & \\
\hline \multirow{6}{*}{ Rutin } & & 0.75 & 5.06 & -3.8 & 2.3 & -0.804 \\
\hline & & 1.5 & 4.7 & -4.4 & 2.85 & -2.78 \\
\hline & & 3 & 0.9 & 3.81 & 2.7 & -2.90 \\
\hline & & 6 & 1.34 & 3.15 & 1.05 & 5.76 \\
\hline & & 9 & 0.5 & $-^{*}$ & 1.6 & $-^{*}$ \\
\hline & & 12 & 0.2 & $-^{*}$ & 0.75 & $-^{*}$ \\
\hline \multirow{5}{*}{ Quercetin } & & 0.5 & 2.88 & -0.676 & 2.6 & -2.43 \\
\hline & & 0.75 & 3.90 & -2.97 & 3 & -6.46 \\
\hline & & 1.5 & 4.80 & -3.89 & 3.1 & -2.40 \\
\hline & & 3 & 5.80 & -8.94 & 2.3 & 0.814 \\
\hline & & 6 & 3.95 & -1.30 & 1.78 & 0.773 \\
\hline \multirow{6}{*}{$\begin{array}{c}\text { Rutin } \\
+ \text { Quercetin }\end{array}$} & Rutin & Quercetin & & & & \\
\hline & 0.5 & 0.5 & 5.5 & -6.59 & 1.96 & -0.0854 \\
\hline & 0.75 & 0.75 & 4.85 & -5.73 & 2.1 & 0.833 \\
\hline & 1.5 & 1.5 & 4.02 & -2.49 & 1.325 & 3.92 \\
\hline & 3 & 3 & 1.15 & 2.15 & 2 & 2.43 \\
\hline & 6 & 6 & 1.10 & 2.93 & 1.55 & 3.82 \\
\hline
\end{tabular}

\# The t-values obtained by unpaired Student's t-tests at $\mathbf{P}=\mathbf{0 . 0 5}$ and $\mathbf{t}$-critical $\approx \mathbf{1 . 6 8 4}$

*t-value could not be obtained as the no. of seeds germinated was less 
Table 4. One way ANOVA analysis showing the effect of Rutin / Quercetin / Rutin + Quercetin on the Root and Shoot lengths of $P$. hysterophorus seedlings, $\mathrm{P}=0.05$

\begin{tabular}{|c|c|c|c|c|}
\hline Chemical added & \multicolumn{2}{|c|}{ For Root Length } & \multicolumn{2}{c|}{ For Shoot length } \\
& F-Value & F-Critical & F-Value & F-Critical \\
\hline Rutin & 6.362 & 3.10 & 6.138 & 3.10 \\
\hline Quercetin & 3.662 & 2.71 & 2.267 & 2.71 \\
\hline Rutin +Quercetin & 7.798 & 2.95 & 1.62 & 2.61 \\
\hline
\end{tabular}

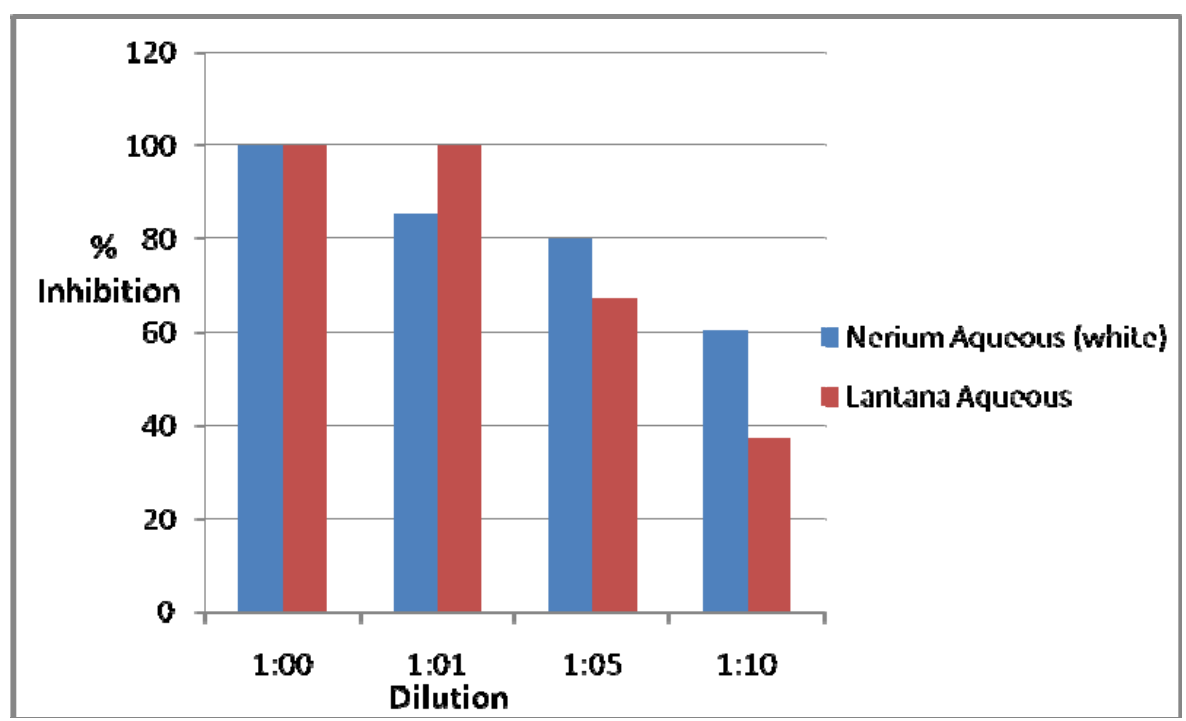

Figure 1. Effect of aqueous extracts of $N$. oleander and L. camara at different dilutions of stock (1:0, 1:1, 1:5 and 1:10) on germination of $P$. hysterophorus seeds

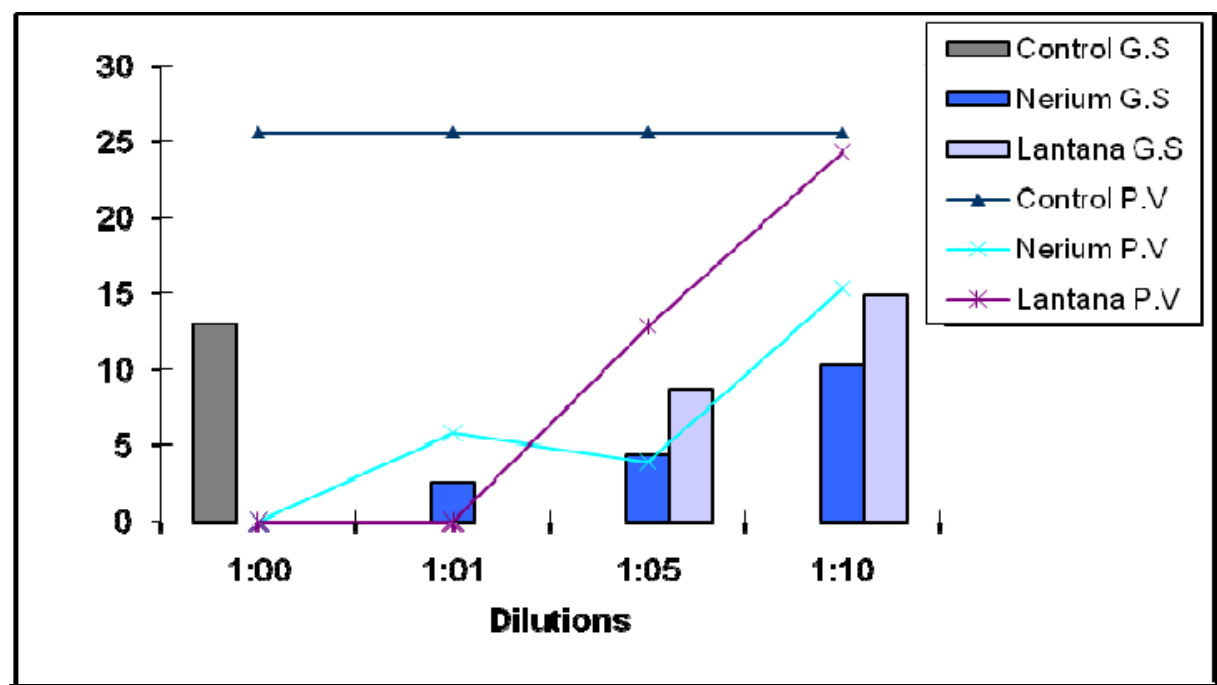

Figure 2. Effect of various dilutions (1:0,1:1, 1:5 and 1:10 of stock solutions) of aqueous extracts of $N$. oleander and L. camara on Peak value (P.V) and Germination Speed (G.S) of P. hysterophorus seedlings. Bars indicate the G.S while the lines indicate the P.V. 


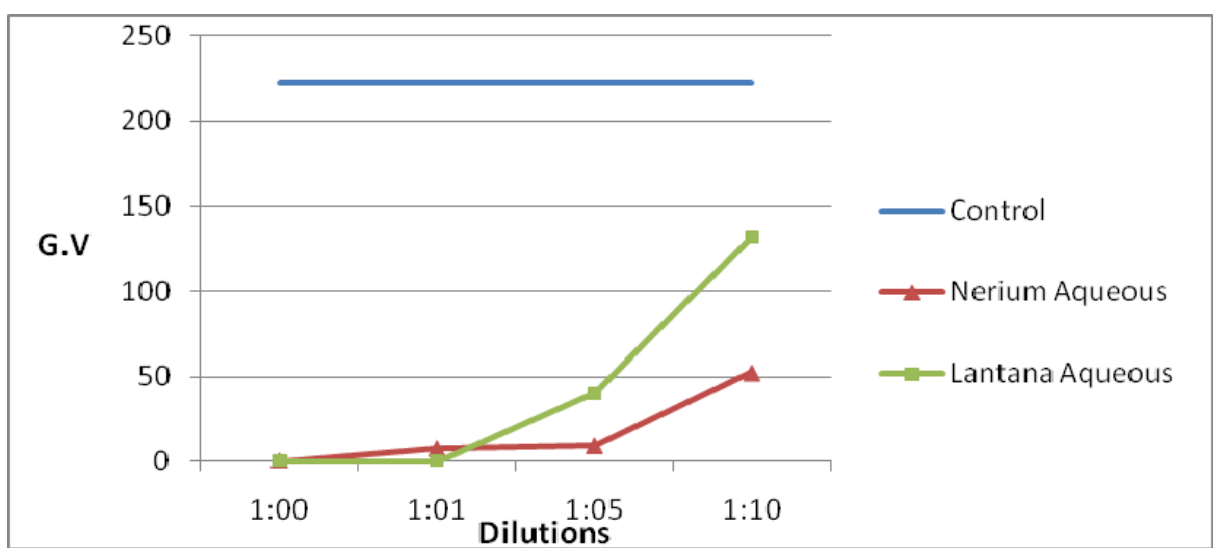

Figure 3. Effect of aqueous extracts of $N$. oleander and L. camara with different dilutions of stock (1:0, 1:1, 1:5 and 1:10) on germination value (G.V) of $P$. hysterophorus seeds

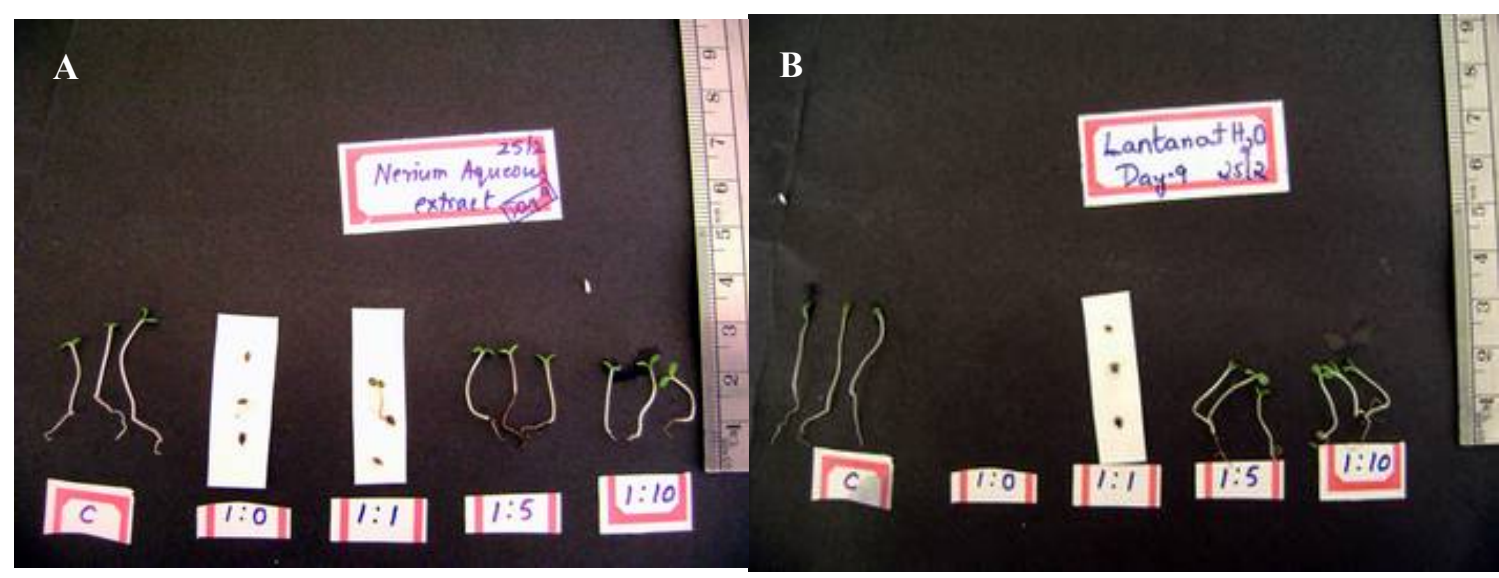

Figure 4. Effect of $N$. oleander and L.camara aqueous extracts on germination of P. hysterophorus seeds. (A) Effect of Nerium aqueous extract: From left to right -controls \& samples treated with 1:0, 1:1, 1:5 and 1:10 dilutions of stock. (B) Effect of Lantana aqueous extract: From left to right are controls \& samples treated with 1:0, 1:1, 1:5 and 1:10 dilutions of stock preparation

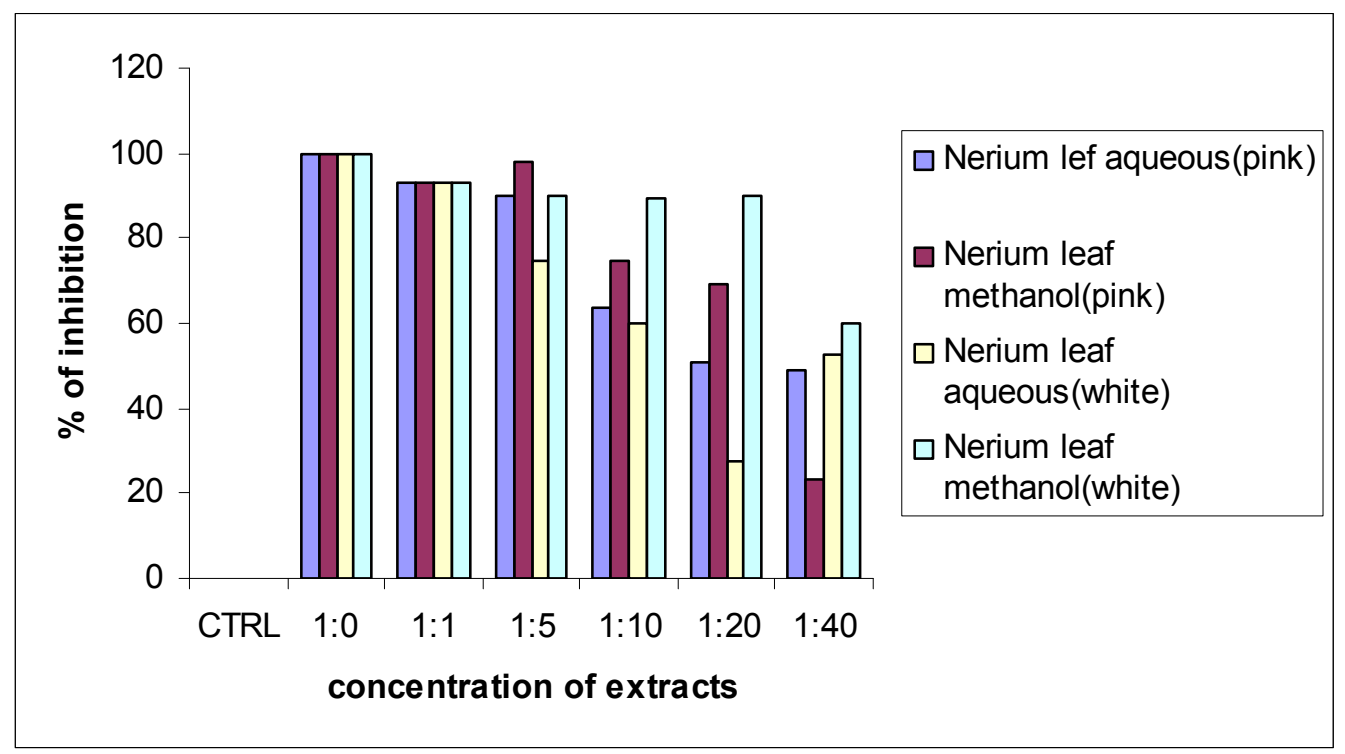

Figure 5. Inhibitory effects of aqueous and methanol extracts of $N$. oleander (pink and white varieties) at different dilutions of stock on $P$. hysterophorus seed germination 


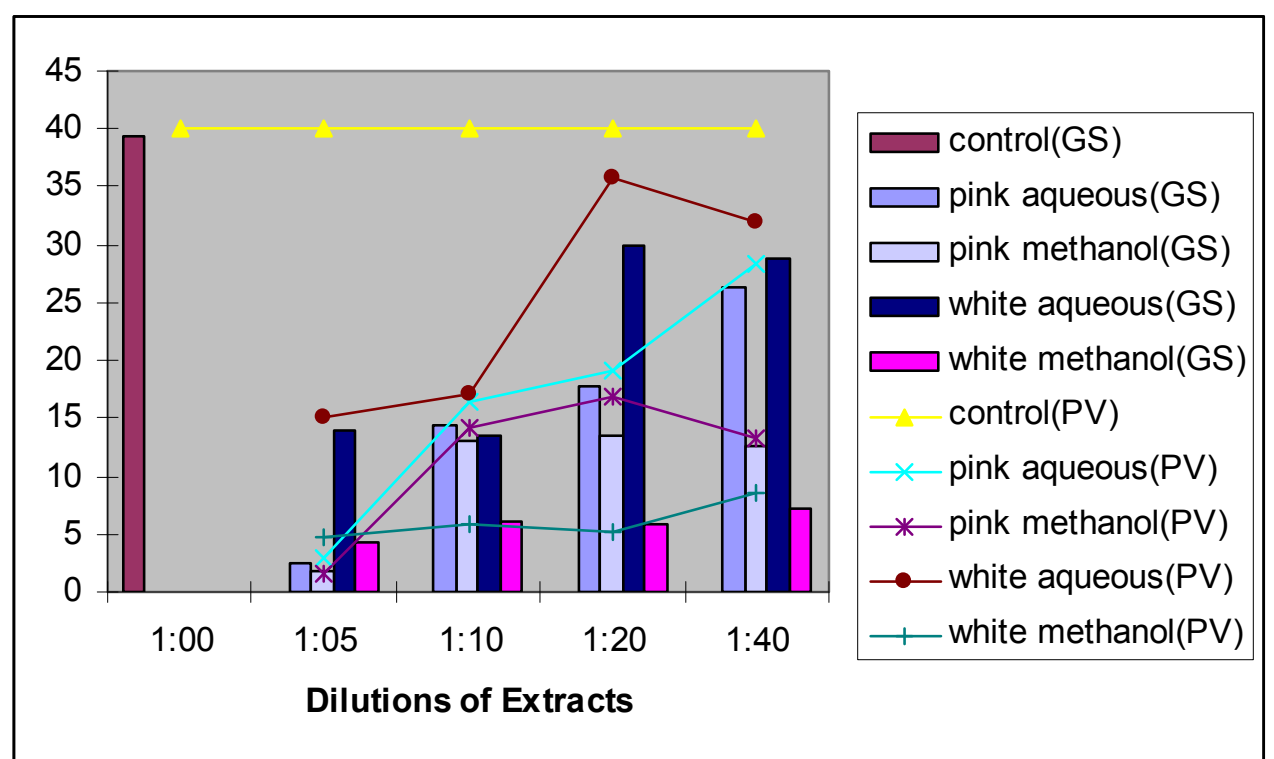

Figure 6. Effect of various dilutions (1:0, 1:5, 1:10, 1:20 and 1:40 of stock solutions) of aqueous and methanol extracts of $N$. oleander (pink and white varieties) on Peak value (P.V) and Germination Speed (G.S) of $P$. hysterophorus seedlings. Bars indicate the G.S while the lines indicate the P.V.

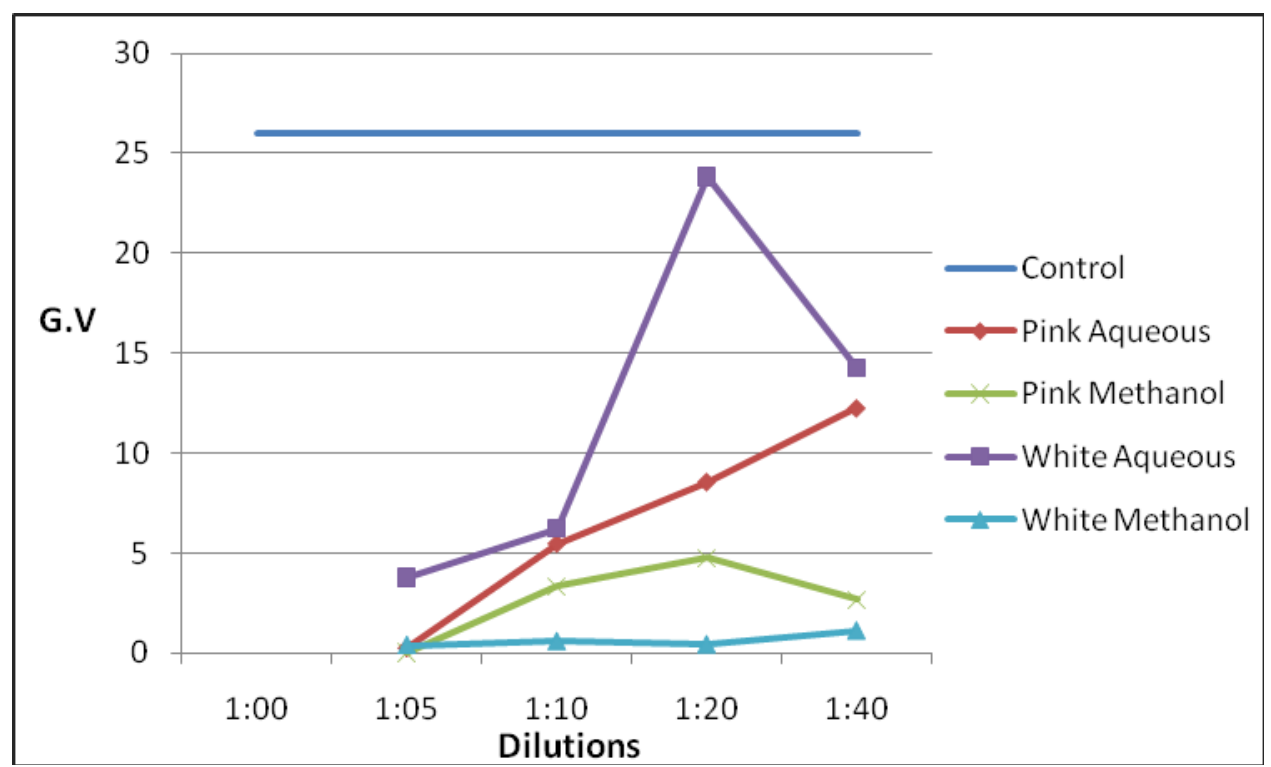

Figure 7. Effect of aqueous and methanol extracts of $N$. oleander (pink and white varieties) (1:0, 1:5, 1:10, 1:20 and 1:40 dilutions of stock) on germination value (G.V) of $P$. hysterophorus seeds 


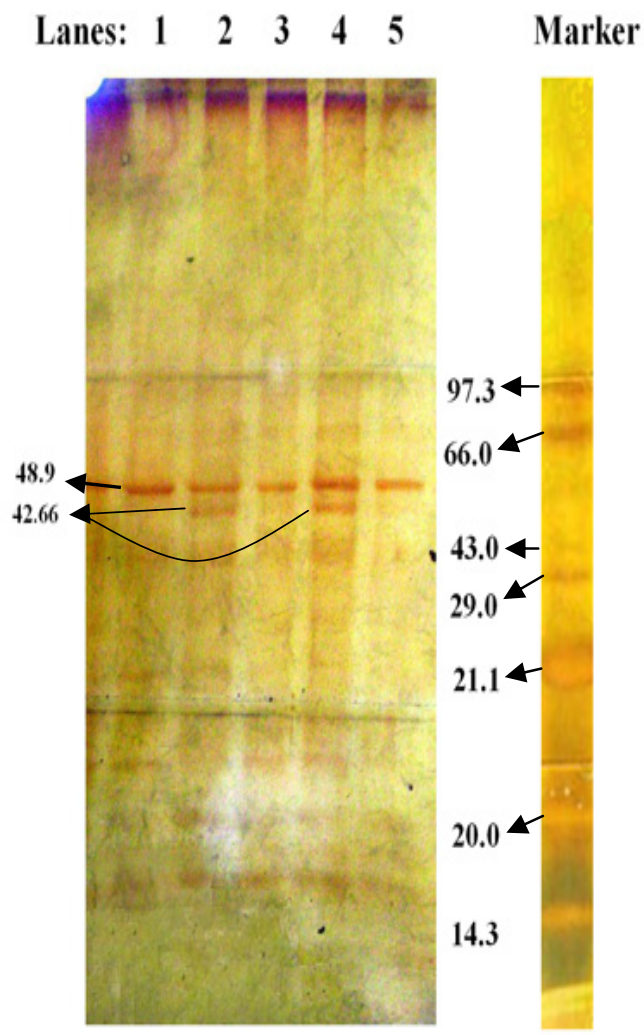

Figure 8. Discontinuous gradient SDS-PAGE of total protein preparation of seedlings. The seeds were germinated and grown in presence of aqueous / methanol extracts of N. oleander / L. camara. Lane 1- Control. Lanes 2 \& 3 seedlings treated with $N$. oleander aqueous and methanol extract respectively. Lanes $4 \& 5$ - seedlings treated with L. camara aqueous and methanol extract respectively

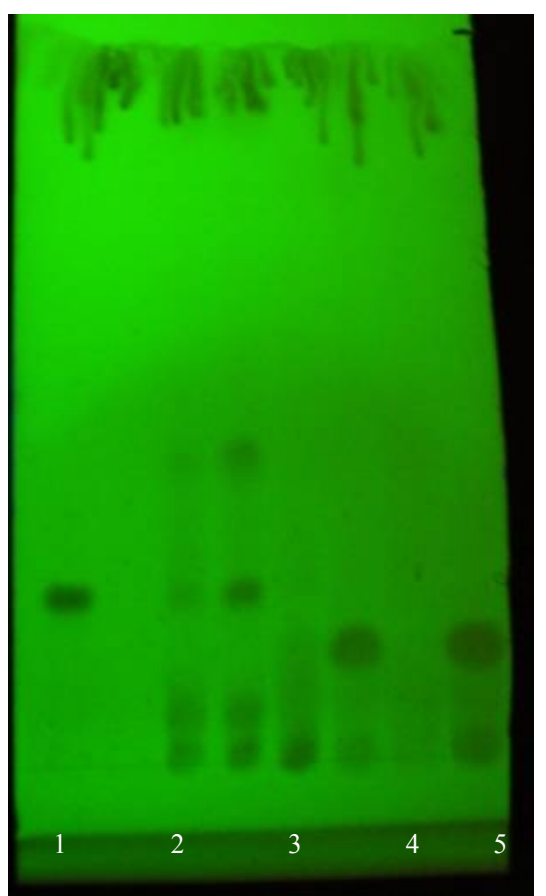

Figure 9. TLC results showing the Rutin band in methanol extracts of both white and pink varieties of Nerium Lane 1: Standard Rutin

Lane 3: $N$. oleander (pink leaf extract)

Lane 4: $N$. oleander (white leaf extract)

Lane 6: $N$. oleander (pink root extract)

Lane 7: $N$. oleander (white root extract) 


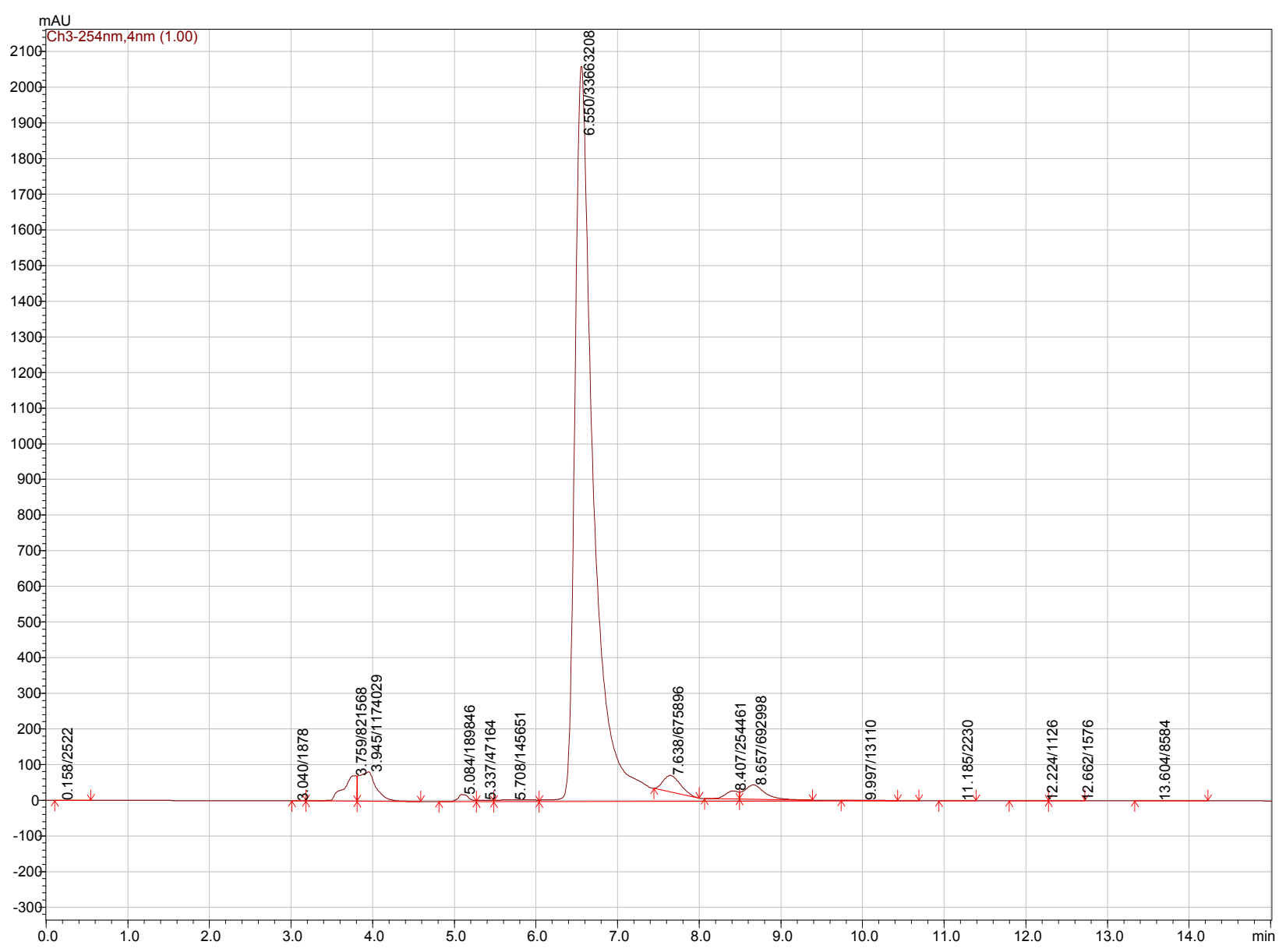

Figure 10. Chromatogram showing the peak obtained by the reverse phase HPLC of pure Rutin standard. Peak corresponding to Rutin is seen at retention time $6.550 \mathrm{~min}$ with peak area 33663208

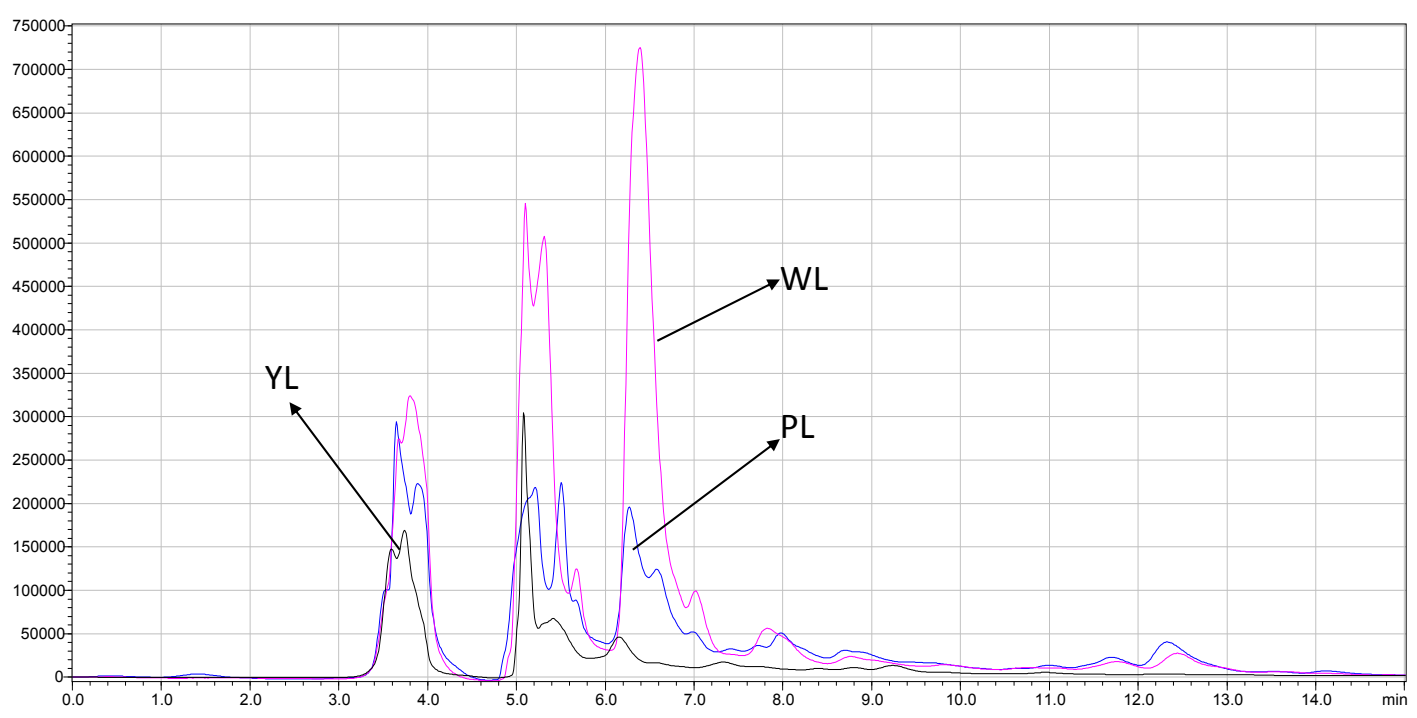

Figure 11. Chromatogram showing the peak obtained for Rutin in pink (PL) and white (WL) N. oleander with corresponding peak areas 33663208,16150164, and retention time 6.265, 6.384, respectively. Extracts of yellow oleander (YL) were also processed and superimposed here 


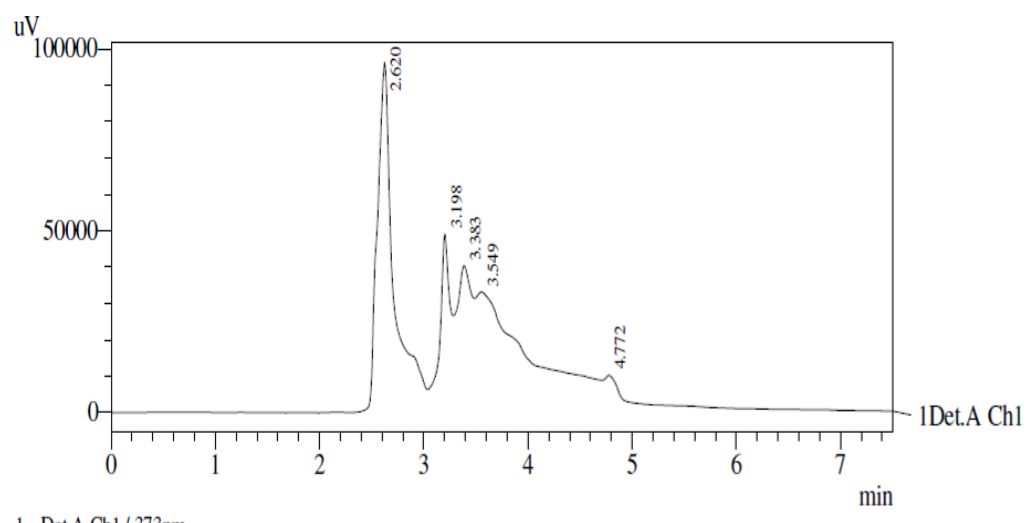

1 Det.A Ch1 $/ 373 \mathrm{~nm}$

Figure 12. Chromatogram showing the peaks obtained by the reverse phase HPLC of $N$. oleander aqueous extract. Peak corresponding to Rutin seen at retention time $2.620 \mathrm{~min} \&$ that of Quercetin at $3.549 \mathrm{~min}$

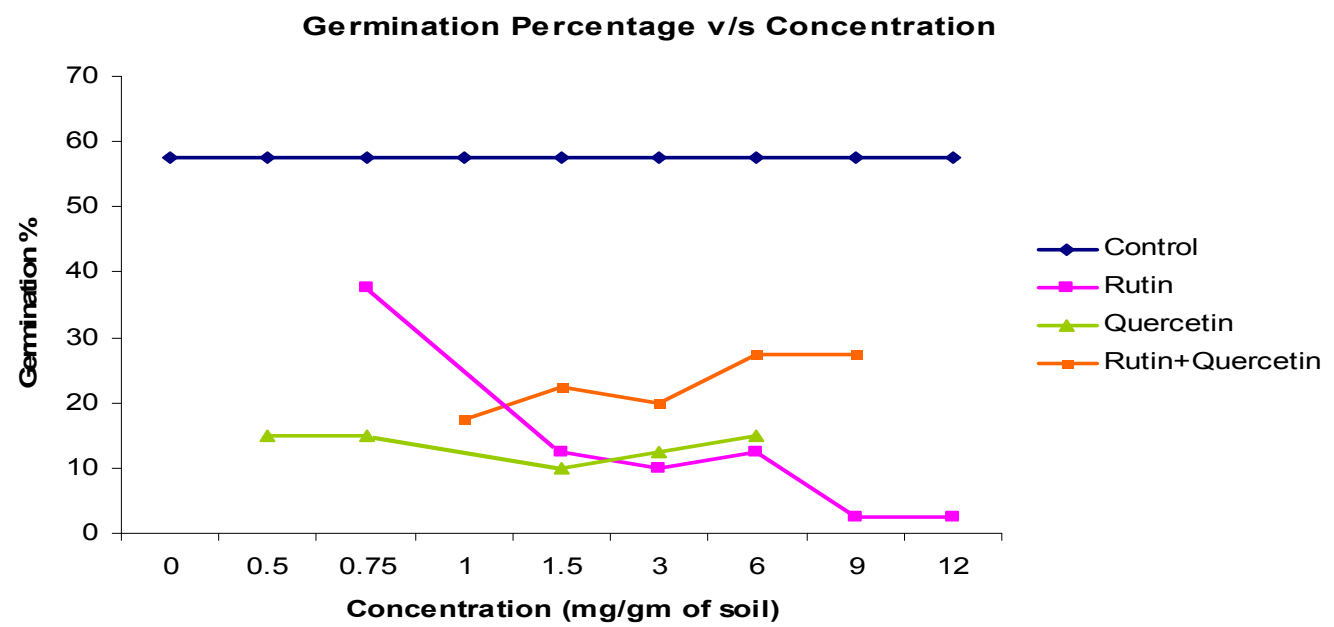

Figure 13. Effect of Rutin, Quercetin and Rutin +Quercetin on germination $\%$ of P. hysterophorus seeds in soil. Rutin treated at $0.75,1.5,3,6,9$ and $12 \mathrm{mg} / \mathrm{gm}$ of soil, Quercetin at $0.5,0.75,1.5,3,6 \mathrm{mg} / \mathrm{gm}$ of soil, Rutin + Quercetin at $0.5,0.75,1.5,3$ and $6 \mathrm{mg}$ of each chemical /gm of soil

Germination Speed and Peak Value of P.hysterophorous at Different Concentrations of Rutin, Quercetin and Rutin+Quercetin

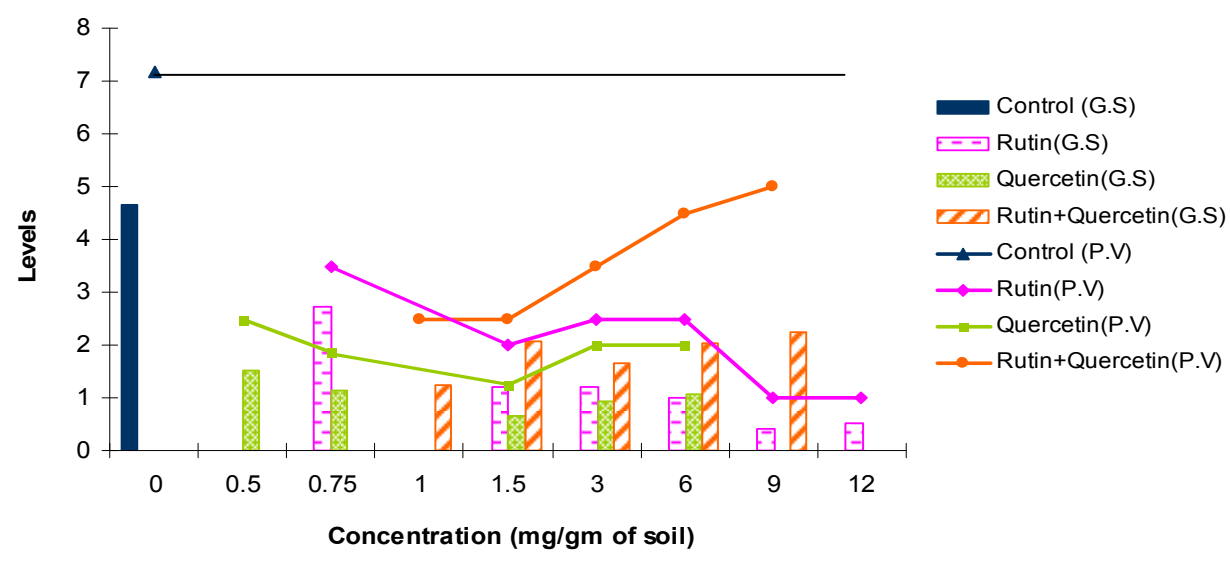

Figure 14. Effect of Rutin, Quercetin and Rutin+ Quercetin on Peak value (P.V) and Germination Speed (G.S) of $P$. hysterophorus in soil. Rutin treated at $0.75,1.5,3,6,9$ and $12 \mathrm{mg} / \mathrm{gm}$ of soil, Quercetin at $0.5,0.75,1.5,3,6$ $\mathrm{mg} / \mathrm{gm}$ of soil, Rutin + Quercetin at $0.5,0.75,1.5,3$ and $6 \mathrm{mg}$ of each chemical /gm of soil. Bars indicate the G.S and lines indicate the P.V. 


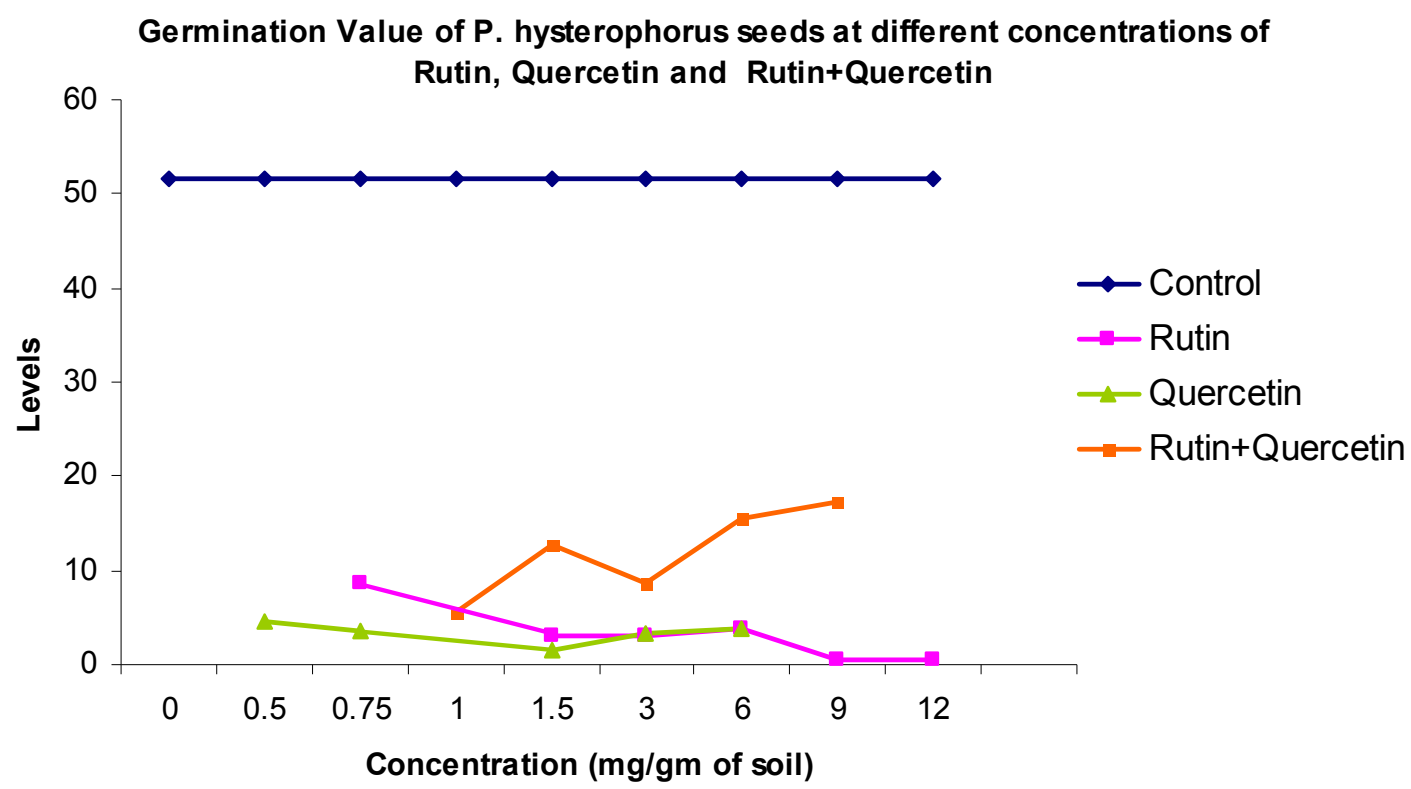

Figure 15. Effect of Rutin, Quercetin and Rutin +Quercetin on Germination Value (G.V) of P.hysterophorus seedlings in soil. Rutin treated at $0.75,1.5,3,6,9$ and $12 \mathrm{mg} / \mathrm{gm}$ of soil, Quercetin at $0.5,0.75,1.5,3,6 \mathrm{mg} / \mathrm{gm}$ of soil, Rutin + Quercetin at $0.5,0.75,1.5,3$ and $6 \mathrm{mg}$ of each chemical/gm of soil

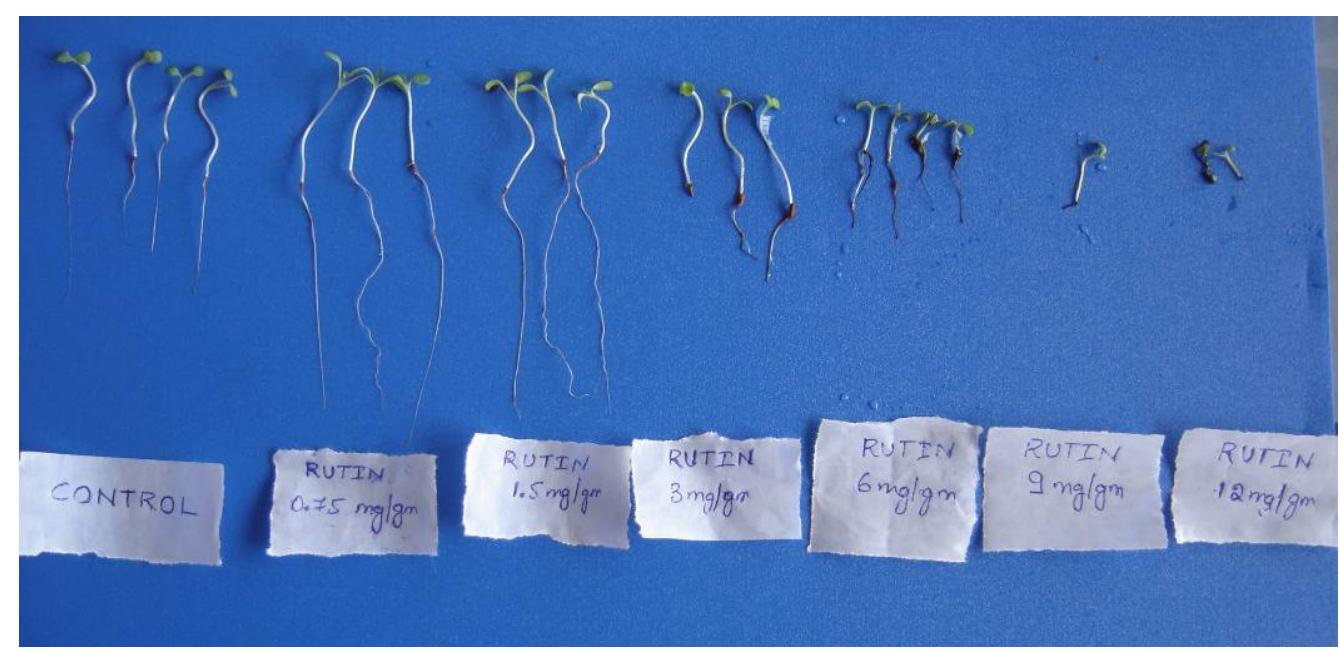

Figure 16. Effect of Rutin on P. hysterophorus seed germination in soil (Petri plates): from left to right -controls, samples treated with $0.75,1.5,3,6,9$ and $12 \mathrm{mg} / \mathrm{gm}$ of soil 


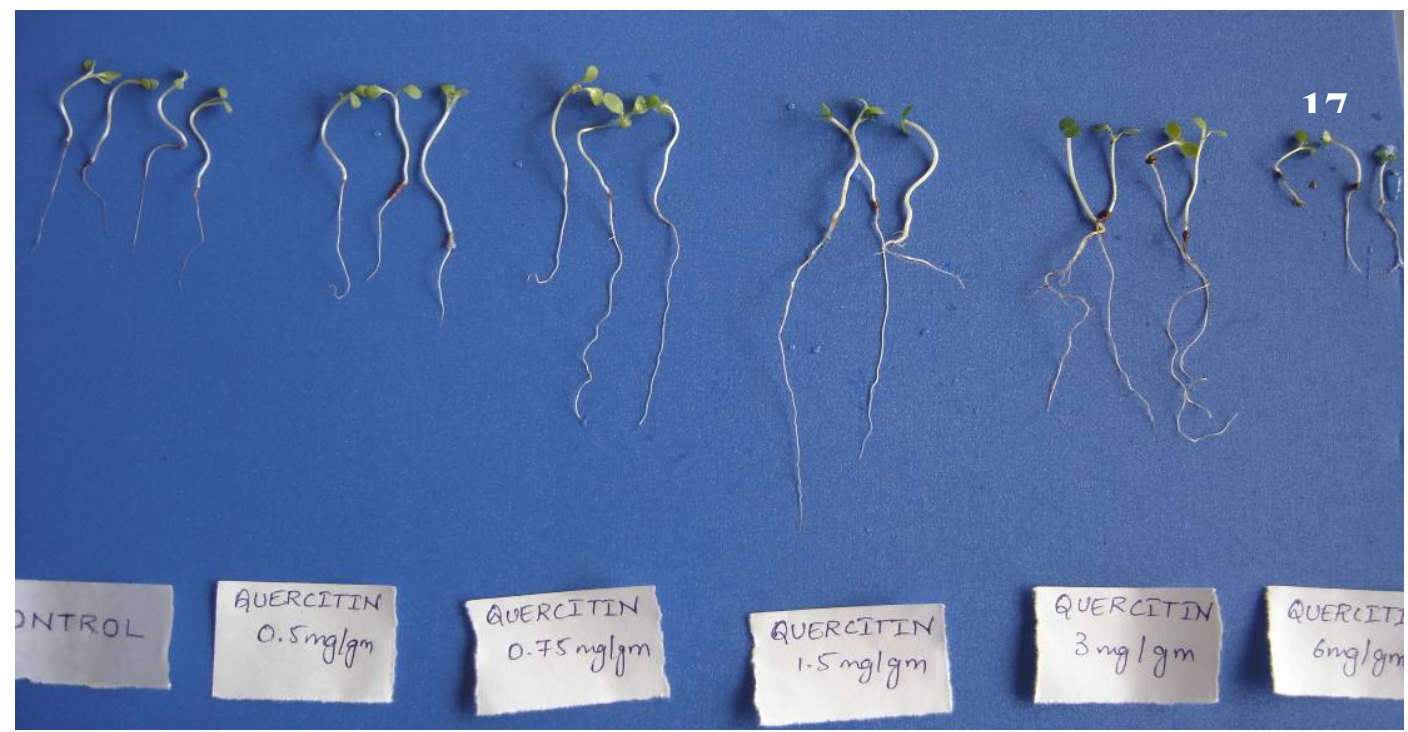

Figure 17. Effect of Quercetin on P. hysterophorus seed germination in soil (Petri plates): From left to right controls, samples treated with $0.5,0.75,1.5,3$ and $6 \mathrm{mg} / \mathrm{gm}$ of soil

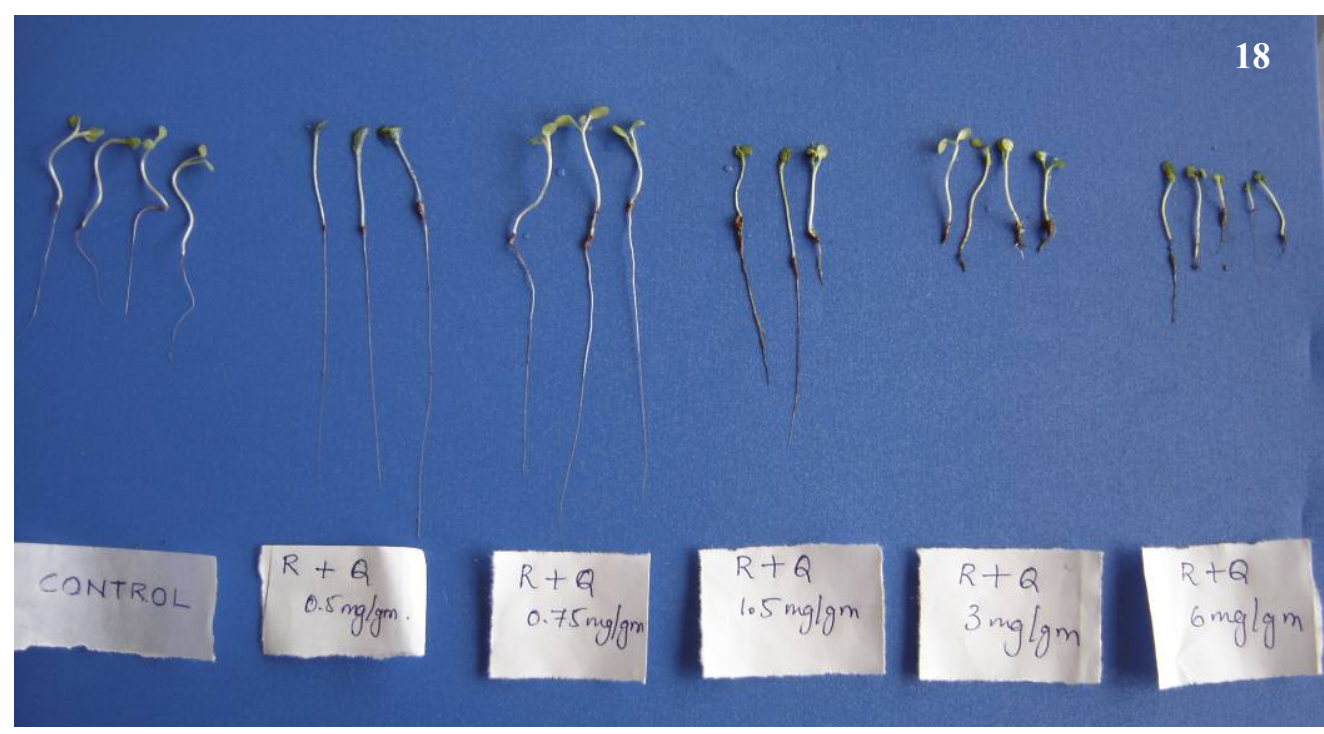

Figure 18. Effect of Rutin and Quercetin on P. hysterophorus seed germination in soil (Petri plates): from left to right - controls, samples treated with $0.5,0.75,1.5,3$ and $6 \mathrm{mg}$ of each chemical /gm of soil 